\title{
Genadz Tsykhun
}

The National Academy of Sciences, Minsk (Belarus)

Email: henadz.cychun@gmail.com; inlinasbel@tut.by

ORCID: https://orcid.org/0000-0002-7075-3994

\section{The Etymological Commentary on Word Formation of Abstract Nouns with the Final Formant - $4 \mathbf{6}$}

Komentarz etymologiczny do derywacji rzeczowników abstrakcyjnych na -ub

Этымалагічны каментар да словаўтварэння абстрактных назоўнікаў на -иь

\begin{abstract}
The article explores the word formation of abstract nouns with the final formant $-u b$ in Belarusian. It also reveals the increased use of this formant in the sphere of concrete nouns. The group analysis of this word formation type allows the overcoming of the 'formal isolation' of a number of words and offer their etymologization. The research considers the origin of some words with the final $-u b$ related to the field of natural phenomena (weather, climate, etc.): гогоиь 'ice on the trees', голиь 'sleet with snow', шаиь 'frost', as well as some abstract nouns: dohać 'consolation', трэпяиь 'something very white', сыць 'whimsicality' etc. The class of the nouns, distinguished on formal grounds, continues the Proto-Slavic word-formation type but also demonstrates some innovative trends. The possibility of the language contacts' influence on the word formation of the nouns with final $-u b$ is stated.
\end{abstract}

Keywords: abstract nouns, language contacts, the Belarusian language, word formation, formant -u̧b, etymology

\begin{abstract}
Abstrakt
Przedmiotem analizy jest słowotwórstwo rzeczowników abstrakcyjnych języka białoruskiego z formantem $-u b$. W toku analizy udowodniono, że rzeczowniki konkretne również często przybierają wymieniony formant słowotwórczy. Analiza zebranych derywatów pozwoliła opisać nie tylko strukturę formalną licznych leksemów, ale także ich cechy etymologiczne. Opisowi poddano pochodzenie zbioru wyrazów z formantem -u̧b, należących do pola semantycznego 'zjawiska przyrody (atmosferyczne, klimatyczne i in.)', np. гогоць 'gołoledź na drzewach', голць
\end{abstract}


'gołoledź i śnieg', mauь 'szron', oraz wybrane rzeczowniki abstrakcyjne, np. dohać 'pocieszenie', трэпяиь 'coś bardzo białego', сыиџь 'kaprysy' itd. Ze względu na budowę słowotwórczą analizowana klasa rzeczowników stanowi kontynuację prasłowiańskiego typu słowotwórczego, wykazuje jednak nowe tendencje. Na podstawie przeprowadzonego badania można wnioskować o wpływie kontaktów językowych na proces derywacji rzeczowników z formantem -ųb.

Słowa kluczowe: rzeczowniki abstrakcyjne, kontakty językowe, język białoruski, słowotwórstwo, formant $-u, b$, etymologia

\section{Анатацыя}

У артыкуле даследуецца словаўтварэнне абстрактных назоўнікаў з канцовым фармантам - ъь у беларускай мове. Выяўлена пашыранае ўжыванне назоўнікаў з гэтым фармантам і у сферы канкрэтных назоўнікаў. Групавы аналіз гэтага тыпу ўтварэнняў дазваляе пераадолець 'фармальную ізаляванасць' шэрагу слоў і прапанаваць іх этымалагізацыю. Разглядаецца паходжанне шэрагу слоў на -ць, якія адносяцца да сферы прыродных з'яў (атмасферных, кліматычных і інш.): гогощь 'галалёд на дрэвах', голць 'галалёдзіца са снегам', шаџь 'іней', а таксама асобных абстрактных назоўнікаў: dohać 'суцяшэнне', трэпящь 'штосьці вельмі белае', сыщь 'капрызы' і інш. Клас назоўнікаў, вылучаных па фармальным прызнаку, працягвае праславянскі словаўтваральны тып, але дэманструе таксама інавацыйныя тэндэнцыі. Канстатуецца магчымасць уздзеяння моўных кантактаў на словаўтварэнне назоўнікаў на -йь.

Ключавыя словы: абстрактныя назоўнікі, моўныя кантакты, беларуская мова, словаўтварэнне, фармант -иь, этымалогія

\section{bstract nouns have always posed certain problems in their etymology. A Swedish Slavist, Gunnar Jacobson, who was engaged in clarifying the origin of a number 1 of such words, proposed 'найти формальный подход к словам, которые считались этимолоически “безнадежными”" , which would “устранить формальную изоляцию исследуемого слова' (Âkobson, 1969, p. 32). One of such formal approaches is the consideration of the etymology of abstract nouns within separate groups forming a semantic and word-formation community. The derivational analysis has a special weight in the etymology, which, apparently, can explain the fact that the first volumes of the major work of Franciszek Sławski entitled Stownik prastowiański ${ }^{3}$ contains an essay about the Slavonic word formation (SP 1, pp. 43-141; 2, pp. 13-60). It determined the nature of the dictionary, which, unfortunately, was not continued.}

\footnotetext{
1 'to find a formal approach to the words that were considered etymologically "hopeless""

2 'eliminate the formal isolation of the investigated word'

3 'Proto-Slavic dictionary'
} 
In the general composition of Belarusian nouns which end in - $u b$ and are characterised by an 'адцягненым' / 'detachment' meaning, nouns with the -асиь / -осиь suffix prevail (Scâcko, 1977, p. 127). In the process of language development, these significantly prevailed in quantity over the relatively small the group of nouns belonging to the pre-Slavic state which end in -cub and can include newly-formed words like the noun жарсиь 'passion' (from жар / heat, see: ÈSBM 3, p. 216), as well as the formations with the $-j b$ suffix with broad semantics. The latter formations are etymologically of the greatest interest in the whole group of abstract nouns ending with - $u b$, where this formant can be attached to the extended stem or directly to the root, or it may enter into its composition and form a meaning with a high degree of presence of some feature inherent in this stem or root, cf. for example: 'Любіць яна пазіраць, як рабая даўгалычая свіння цеста апетуе ... A сыщь тая, сыщь!' (L. Kaliuha). In some dictionaries, the word cыць is explained by means of the word cblmacub (Stankevič, 1990, p. 1113), which does not fully reflect the specific semantics of the word used, see in another dictionary сыщь 'насычэнне, перанасычанасць' / 'satiety, fullness' (Vušackì slovazbor, 2014, p. 159). And the further 'адцягненасць' / 'detachment' of meaning is fixed on the territory of Navahrudčyna: сыщь 'капрызы, самазадаволенасць, эгаізм' / 'caprice, complacency, selfishness': сыць узяла! (Kryval'cèvǐc, 2016, p. 124). Such a clarification of meaning is present in other similar formations: 'Тые олеі náxоиъ!' - is explained as 'вялікі пах' / 'a strong smell' next to the verb пахоце́ць 'моцна пахнуць' / 'strongly smell' (TS 4, 1985, p. 18); 'Зобралосо людзей бázащ̧ь' - when багаиéų means 'узрастаць колькасна і якасна' / 'increase quantitatively and qualitatively' (TS 1, 1982, p. 35). Such parallelism of noun and verb forms may raise the question of the direction of derivation, especially since the corresponding verb is peculiar to the meaning of intensive action, as in cыце́ць 'рабіцца больш сытым, укормленым' / 'to become more full, well-fed'. Compare the expression 'Сыць вам!' 'пажаданне, ветлівае вітанне тых, хто ў гэты час есць' / 'a wish, a polite greeting to those who are eating at this time' (Kaspârovič, 1927, p. 299), where cblų can be perceived as both a noun and a verb, which confirms another polite wish: 'Сыць, Божа!' 'смачна есці' / 'to enjoy e meal', correlated with the verb сыціць 'насычаць' / 'satiate' (Stankevič, 1990, p. 1113). A possible homonymy of forms can be seen in the rare тхнець 'духмянасць, водар' / 'fragrance, aroma' (чаромхаў тхнець / bird cherry fragrance, Alieś Salaviej) and non-fixed, but potentially existing in the language *тхнець 'моцна пахнуць, адурманьваць пахам' / 'smell strongly, intoxicate by smell', correlated with тхнуиь 'пахнуць' / 'smell', where the meaning of 'дыхнуць, павеяць водарам' / 'breathe, smell aroma' still prevails as a one-time act (ÈSBM 14, 2017, p. 279). For a similar кісляць 'кісляціна' / 'sour, acidic' (Vušackì slovazbor, 2016, p. 80), respectively, it will be rather correlated with the normative кісле́uь 'станавіцца кіслым або больш кіслым' / 'become acidic or more acidic' (ÈSBM 2, 1980, p. 690) than the potentially possible *кіслець 'пракісаць' / 'sour'. In some cases, formal changes may indicate the direction of derivation, compare сьвериь, rus. зуд 'itch' to свярие́ив, свярбе́ць 'часацца' / 'scratch', rus. зудить / 'itch' (Lastoǔskì, 1924, p. 216), труиьь 'атрута' / 
'poison’ to труцьь, труціцьь ‘атручваць' / 'poison' (ÈSBM 14, 2017, p. 42). Very indicative is the record by M. Federowski from the Slonim region: Kab tỳ być ni wièdaŭ (Federowski, 1935, p. 406) with a noun identical to the verb быць / to be.

Thus, there is a separate word-formation and semantic class of abstract nouns ending in $-u b$, which in a generalised form express the concept that in comparable verbs is characterised by the intensity of action or duration of the state, compare in Václav Machek 'intensivum' when characterizing some verbs (Machek, p. 175) and 'глагольный интенсив' / 'verbal intensivum' in A. Trubačev (ÈSSÂ 1, p. 137)4. On the formal side, this class of nouns is determined by the stress on the first syllable in the presence of several syllables in the word.

At first sight, this class of abstract nouns is perceived as inherent exclusively in the vernacular. However, the fixation in the old Belarusian texts of the noun доброть 'yсё добрае як процілегласць злому, дабрата, добрая справа'5 (GSBM 8, p. 146), as well as the presence of similar nouns in other Slavic languages (Polish, old Polish, Slovak, Czech dialect, see: SP 3, p. 307), calls into question the initial conclusion and calls for the search for traces of similar formations in Proto-Slavic languages. However, for the old Belarusian noun, borrowing is allowed (Stašajtene, 1973, p. 28), and for the old Ukrainian доброть, the supposed source is the Polish word dobroć (Timčenko 1, 2002-2003, p. 212). A. T. Trubačev considers this noun as a derivative (variant?) from *dobrota (ÈSSÂ 5, p. 44), and A. Bańkowski regards it as an old Polish innovation of the $14^{\text {th }}$ century, which spread in the neighboring languages (Bańkowski 1, 2000, p. 278). The problem is the origin of one more formation ending in $-\iota_{b}-$ Belarusian хуць 'хаценне, жаданне', 'прыхільнасць, ахвота' / 'wish, desire', 'passion, affection': Хуци не маю до ее (Nasovič, 1983, p. 685, 750), which is not usually given during the restoration in the etymological dictionaries as the Belarusian realization of Proto-Slavic *chotb or West Slavic *chotb (Boryś, 2005, p. 58, 71) apparently considering the possible borrowing of the Belarusian word through the Polish language from Czech chut' (<*chotěti), compare F. Skaryna хоть / хуть 'жаданне' / 'desire' (PGS 2, 2013, p. 452) derived nóxauь 'памыканне, схільнасць' / 'addiction, attraction' (Lastoǔskì, 1924, p. 508).

But there are old Polish formations ending with $-c$ that are not confirmed in the old Belarusian language, such as świać / święć: nie chcieli chodzić po tej święci $\left(15^{\text {th }}\right.$ century; 'o ogólnym zn. "nazwa miejsca”", Długosz-Kurczabowa, 2003, p. 491).

Based on the description of the Proto-Slavic suffixation of nouns of Franciszek Sławski, it can be assumed that many Belarusian formations with $-u b$ as the final formant can go back to the Proto-Slavic nouns with the *-tb suffix, the last one is characterised as 'tworzący $\mathrm{w}$ psł. zwykle pierwotne abstrakta od pierwiastków

\footnotetext{
4 Yuri Patsyupa to characterise a number of such verbs uses the concept of 'continuality of action' (Pacûpa, 2007, p. 208).

5 'all good as opposed to evil, kindness, good deed'
} 
werbalnych'6, although there are other cases: 'Niewiele jest przykładów na derywaty od pierwiastków niewerbalnych"7 (Sławski, 2011, pp. 158-159). As an example of the latter, it is possible to quote Viciebsk во́лаць 'танюткія, кшталту нітак, костачкі ў рыбнай мякаці' ${ }^{8}$ (Vušackì slovazbor, 2016, p. 37), which formally corresponds to the Polish wtoć 'асобныя недакошаныя сцябліны, пакінутыя сярод поля', Lithuanian váltis 'колас аўсу, мяцёлка' / 'ear of oats, raceme' and goes back to the Proto-Slavic *voltb (Fasmer, 1964, p. 344), despite the varied semantics commonly associated with во́лас. Here, the abstract character of the noun is realised in the concept of 'collection', cf. in F. Sławski: 'Wyjątkowo tylko spotyka się kolektiwa z suf. -tb' ${ }^{10}$ (Sławski, 2011, p. 158).

In the $14^{\text {th }}$ volume of Этымалагічны слоунік беларускай мовы ${ }^{11}$ there was a question of the origin of several words from the group of nouns ending in - $u b$, which, in addition to the common final formant, showed significant external similarity and even identity with a large discrepancy in semantics. As for the collected mpónaus 'адходы пры трапанні лёну' / 'shives when scutching flax' there were no variants of another origin except from mpanaus 'scutch' (ÈSBM 14, p. 189), especially, when the verb mpэ́naus 'scutch', formally identical to the noun, was analyzed on the same page. As it has been shown above, this quite often occurs in the group of nouns ending with -u̧. However, the nouns трэ́nящь ‘ 'багна, дрыгва' / 'swamp, marsh' and трэ́nящь ${ }_{2}$ 'тое, што вельмі белае' / 'what is very white' (irritates the eyes with its whiteness) remained etymologically dim, especially the latter, which is associated with hapaks with a 'безнадзейная' / 'hopeless' etymology due to its unusual semantics. Their analysis within the class of abstract nouns ending with - $u_{b} b$ allowed for a hopefully satisfactory solution on the basis of the 'intensive' verb трапята́иь 'дрыжаць, трымцець' / 'tremble, shiver' with the further development of the meaning of 'асляпляць мігценнем святла' / 'dazzle by flashing light' (ÈSBM 14, p. 191), compared with the dialectal mpanauiııь 'дрыжаць' / 'tremble' (Volkaǔ, 2016, p. 86).

Observations of the relatively transparent cases of the origin of abstract nouns ending with - $\iota_{b}$ give reasons to project them on a wider range of similar formations in order to clarify the etymology of other abstract nouns of this group of 'цьмяна' / 'dim' nature, in particular, associated with climatic and atmospheric phenomena.

Го́гоць 'галалёдзіца, абліваха' / 'sleet, ice slick': гогоць - наморожня така, падае на траву, ла́міць лес ${ }^{12}$ (TS 1, p. 208). For etymology is essential to clarify the meaning - 'галалёд на дрэвах' / 'ice on the trees', which allows you to associate the word with onomatopoeic гózaџь 'біць адно аб другое, асабліва калі пры гэтым

\footnotetext{
'creating ordinary primary abstracts of verbal elements in the Proto-Slavic language'

'There are few examples of derivatives from nonverbal elements'

'thin, like threads, bones in fish pulp'

'separate not mowed stalks left in the fields'

10 'There is only a collection with the suf. - $t b$ '

11 'The Etymological Dictionary of the Belarusian Language'

12 'ice rain, falls on the grass, breaks the forest'
} 
узнікае гул ${ }^{13}$ (Nasovič, 1983, p. 115). The formal similarity of noun and verb, noted earlier, reinforces the etymology, not to mention the testimony of speakers of Turaŭ speech, who observed this phenomenon in nature (especially a kind of chime of icy branches of a tree). Onomatopoeic basis is present in the archaic saying: 'Благога жарабка дык і на пярэплаце (плоце) шкура гагочаџь '14 (Vušackì slovazbor, 2016, p. 230), which confirms the figurative etymon.

Голиь, гольць 'галалёдзіца са снегам' / 'sleet with snow' (Stankevič, 1990, p. 171). The original Belarusian formation with the final formant $-u b$, which in old Russian and other Slavic languages correspond to nouns in a 'поўнагалосная форма' / 'full-sounding, sonorous' form, compare Russian го́лоть, Polish gołoć, Czech holot' and others, that gives reasons for the reconstruction of the Proto-Slavic *golotb / *golbtb, derived from *golъ 'голы' / 'naked' (ÈSSÂ 6, p. 214; SP 8, p. 74). It is possible that the Belarusian dialects preserved the corresponding 'інтэнсіўны' дзеяслоў / 'intensive' verb from the same basis, compare гальке́ць 'гараваць, жыць у беднасці, нястачы' / 'grieve, live in poverty, need' (ŽNS, 2001, p. 129), recorded in the territory (Vušaččyna), where instead of $u$ ' there is $\kappa$ '. According to Paul Wexler, 'the northeastern Belarusian dialect innovation could form isoglosses with the Novgorod dialect of the Russian language (cf. Russian в лавке 'у краме' / 'in the store')' (Vèksler, 2004, p. 193). For the semantics compare Russian dialect голе́ча 'галалёдзіца на дарозе' / 'ice on road' and the Belarusian гале́ча 'голь, беднякі' / 'beggar, the poor'. We can assume that голиь is a newly-formed word compared to the old Belarusian голоть, which by the way has already been offered by T. Gorjačeva during the reconstruction of гол(о) ць with a lost $o$ for the explanation of the above mentioned гогоu $b$ with replacement $2 \rightarrow \pi$ (Gorâčeva, 2007, p. 40), but the latter seems doubtful due to the assumption of 'vertical' change of consonants. However, Vladimir Orel connects the Belarusian form with the Russian one, оголте́лый 'дзікі, ашалелы' / 'wild, rabid' (Orel 2, 2007, p. 360), which undoubtedly is based on the 'intensive' verb of the *gzltěti type (cf. *obgъltěti, ÈSSÂ 27, p. 52). The rare Belarusian word агалце́лы 'звар'яцелы, дурны' / 'mad, stupid' was deduced by Vaclaŭ Lastoŭski from the root гал-, to which he attributed and ага́льныл 'нахрапны і непрыязны / impudent and unfriendly' (Lastoǔskì, 1997, p. 419), as attested in the Bransk region: ага́л 'о злом, завистливом человеке' / 'about wrong, envious man' ('Их завуть агаламы, злыи люди, агалтельи люди'; BOS, 2007, p. 14) ${ }^{15}$. This may, apparently, refer to the Belarusian word оголичть (агалщіць?) 'наслаць хваробу нагаворам або сурочыць' / 'to send a disease with a hex or jinx', written down by Aleksandr Afanasyev. The connection of these words with голиь, as well as their etymology remains unclear (Žuravlev, 2005, p. 214), but it is possible, as will be shown below, that the 'magic'

\footnotetext{
13 'beat one against the other, especially if there is a buzz'

14 'At a bad foal and on the fence the skin is buzzing'

15 Vitebsk агалам has the meaning 'together' (Vušackì slovazbor, 2016, p. 17).
} 
semantics of the verb can correlate in a certain way with the specific meaning of the nouns correlated with it.

Шаць 'іней, шэрань; сырасць у паветры, якая асядае на рэчы і замярзае пушком' / 'frost, hoarfrost; dampness in the air, which settles on things and freezes down like a fluff' (Lastoǔskì, 1924, p. 224, 270; Stankevič, 1990, p. 1122). In this meaning, this word occurs mainly in the dialects adjacent to the Baltic language territory (LABNG 2, m. 44), compare šac' from the Braslaŭ region, which is used as a relevant to the Polish szadź 'іней, шэрань' / 'frost, hoarfrost' (Smułkowa, 2009, p. 733) in an adapted form ('hissing' $c$ ' instead of $d z$ ), which allows for including the noun into the group with the final formant $-u b^{16}$. The etymology of the word is reflected in the Belarusian шэ́рань (from шэры 'gray', which goes back to *šarъ / *šerъ 'шэры, сівы' / 'gray, grey' in the West Slavic *šadı 'gray', see: Boryś, 2005, p. 591). The problem is known in the same territory * шаце́ць, compare шаціиц 'трызніць' / 'rave': У гаручцы чалавек шаціи $b^{17}$ (BD 3, p. 80), whose connection with maus is confirmed by the recording šac 'ic', bl'uz'nic', l'ažlyc' jak stata (Smułkowa, 2009, p. 347) where stat a means 'mokra pogoda' / 'wet weather' (Smułkowa, 2009, 728) ${ }^{18}$. Thus, the structure of 'abstract noun' - 'intensive verb' is restored. Here the abstract noun maub 'зброд' / 'rabble' joins: Адна шащьь кругом, звяліся людзі ${ }^{19}$ (Vušackì slovazbor, 2016, p. 183). It is possible that this is a shortened form of the ша́ція 'кампанія хуліганаў' I 'a company of hooligans' (Ûrčanka, 1969, p.102), borrowing ша́тия 'кампанія людзей непрыстойных паводзін' / 'a company of people of indecent behavior' from the Russian vernacular, formed on the model of the Church Slavonic бра́тия from шата́ться 'бадзяцца' / 'wander' (ESUM 6, p. 388) 20, but in the group of Belarusian nouns ending in $-\iota, b$, it received an expressive connotation under the influence of the figurative semantics of the word шэ́рань; compare also: Напала шаиь на дзерава ${ }^{21}$ (Šatalava, 1975, p. 199).

16 Incidentally, such cases of 'stunning' of the final (etymological) - $\partial 3$ ' are observed in other nouns, indicating the expansion of the use of the formant $-u_{\mathrm{b}}$ in the Belarusian language, compare галале́й 'the same as ice slick' (SIPZB 1, p. 408), recorded in the Ashmyany district and in Kraslavshchyna. Taking into account this phenomenon, we can interpret the mysterious dohac 'repentance': Boh jemu daŭ dohać, ciper czeławiekam staŭ / The Lord repented him, and he became a man (Federowski), recorded near Valkavysk; most probably it goes back to дагадзіuь 'console'.

17 'in a fever, a person is raving'

18 Compare the variant слоць 'слякоть' / 'sleet' in The Russian - Belarusian Dictionary (Ârušèvìc, 2018, p. 284).

19 'There are no other people but the rabble around'

20 Oleksa Gorbach deduced the Ukrainian argotic word шатія with Yiddish šutvis 'суполка' / 'community' (Gorbač, 1966, p. 23), compare Yiddish šutfes 'accessory, community' (Astravuh, 2008, p. 728), because of the other vocalism is difficult to prove.

21 'Frost fell on a tree' 
However, it is more likely that the atmospheric phenomenon is related to the close value of 'покрыва (з лісця, снегу)'22 (TSBM 5, p. 359), presented in a similar ша́иьце 'убор, строй, адзенне' / 'attire, suit, clothes': Багатаму не шкода й шаиьия, а беднаму жаль і шмаиьия ${ }^{23}$ (Sieržputoŭski). The latter is elevated to the category of mámbl 'clothing' with unreliable etymology (ESUM 5, p. 288), perhaps of a Proto-Slavic origin (Schuster-Šewc, 3, p. 1408). The homonymous abstract word ша́mы as used in the expression mаты водзящь 'пра фізічны стан чалавека, які вызначаецца слабасцю' / 'about the physical state of man, which is determined by weakness' (Volkaǔ, 2016, p. 96), apparently, confirms the latter, attaching a mythological element thereto, unless it is a secondary formation from *šętati 'wander'.

Summing up the results of the etymological derivation of abstract nouns with the final formant $-u b$, it is necessary to note that this formally selected group of words in the Belarusian language is characterised by a tendency to word-formation and semantic consolidation based on the Slavic derivational inheritance on one hand, and on a distinct expansion of the specified formant on the other, not only in the sphere of the abstract, but also in the sphere of specific vocabulary. Something similar was pointed out by Jan Otrębski in respect of the Lithuanian language, in the case of the nouns with the -tis, -ties suffix (Otrębski, 1965, p. 241), which may be regarded as a joint feature resulting from geographical factors. According to Otrębski, nomina actionis with these suffixes derived from verbs, or, more precisely, from their roots, partially retained their primary semantics, and partially received a specific meaning. It is interesting that most nouns belong to the feminine gender and their first syllable is stressed. This clear typological similarity in the absence of direct sources of borrowing $\mathrm{s}^{24}$ indicates, most likely, the relations characteristic of language unions. Interestingly enough, Otrębski notices the archaic character of similar Lithuanian formations ('tworzenie nowych wyrazów za pomocą przyrostka -ti- dawno już ustało' ${ }^{25}$, Otrębski, 1965, p. 241), while the Belarusian dialects exhibit an extension of nouns with the final formant $-u b$. As can be seen from the study, these are used throughout the entire Belarusian language territory, but their greatest concentration is visible in the North-West, including all formations with the $-j b$ suffix. However, perhaps there is a subjective factor (in the dictionary of V. Lastoŭski, who originated from Dzisienščyna, 'россыпы ўтварэньняў на -jb уражваюць сваёй колькасьцю, непрапарцыянальна вялікай у параўнаньні да мовы літаратурнае ${ }^{26}$,

22 'cover (of leaves, snow)'

23 'The rich do not feel sorry for clothes, and the poor feel sorry for rags'

24 Among the 'concrete' nouns ending $\mathrm{n}-u_{\mathrm{b}}$ found in the Belarusian dialects, it would be possible to attribute the word кinяus 'the cheapskate, the miser' (Ragaǔcoǔ, 2002, p. 2) or identical кinяus 'the rigid forest grass' (Kryval'tsevich, 2016, p. 68), probably connected with lit. kipti 'cling, grab' to potentially possible baltisms, but the exact Baltic matches have not yet been found.

25 'the formation of new expressions with the help of the suffix -ti- has ceased long ago'

26 'concentration of the formations ending in $-j b$ is impressive in their number, disproportionately large in comparison with the language of literature' 
Pacûpa, 2007, p. 201), but the other sources regarding the nouns with the final formant $-u b$ confirm the spatial 'expansion' of this formant from the Northwest.

Translated into English by Marharyta Svirydava

\section{List of sources}

Âruš̀̀vič, Apanas. (2018). Rasejska-belaruskì sloǔnik. Arhiǔnâ spadčyna. Mìnsk: Belaruskaâ navuka. [Ярушэвіч, Апанас. (2018). Расейска-беларускі слоўнік. Архіўная спадчына. Мінск: Беларуская навука].

Astravuh, Alâksandar. (2008). İdyš-belaruskì sloǔnik: z prykazkamì, prymaǔkamì, vysloǔâmì, frazèmamì, paraǔnan'nâmì, zyčan'nâmì, vitan'nâmì, dražnilkami-kepikamì, praklënamì, zagadkamì, skoragavorkamì, kalamburamì, cytatami z žydoǔskih pesen', anèkdotaŭ ì litaraturnyh tvoraŭ. Mìnsk: Medison. [Астравух, Аляксандар. (2008). Ідыши-беларускі слоўнік: з прыказкамі, прымаўкамі, выслоуямі, фразэмамі, параўнаньнямі, зычаньнямі, вітаньнямі, дражнілкамі-кепікамі, праклёнамі, загадкамі, скорагаворкамі, каламбурамі, цытатамі з жыдоусскіх песень, анэкдотаў і літаратурных творай. Мінск: Медисон].

Bańkowski, Andrzej. (2000). Etymologiczny stownik języka polskiego. Vol. 1-2. Warszawa: Wydawnictwo Naukowe PWN.

BD - Belaruskaâ dyâlektalogiâ: matèryâly ì dasledavannì. (2010 and the next). Issue 1-5. Mìnsk: Belaruskaâ navuka. [Беларуская дыялекталогія: матэрыяльы і даследаванні. (2010 і наст.). Вып. 1-5. Мінск: Беларуская навука].

Boryś, Wiesław. (2005). Stownik etymologiczny języka polskiego. Kraków: Wydawnictwo Literackie.

BOS - Golovanevskij, Arkadij (ed.). (2007). Brânskij oblastnoj slovar'. Brânsk: Brânskij gosudarstvennyj universitet. [Голованевский, Аркадий (ред.). (2007). Брянский областной словарь. Брянск: Брянский государственный университет].

Długosz-Kurczabowa, Krystyna. (2003). Nowy stownik etymologiczny języka polskiego. Warszawa: Wydawnictwo Naukowe PWN.

ÈSBM - Cyhun, Genadz' (ed., Vol. 1-8 ed. Viktar Martynaŭ). (1978 and the next). Ėtymalagičny sloǔnik belaruskaj movy. Vol. 1-14. Mìnsk: Belaruskaâ navuka (Navuka ì tèhnika). [Цыхун, Генадзь (рэд., т. 1-8 рэд. Віктар Мартынаў). (1978 і наст.). Этылмалагічны слоўнік беларускай мовы. Т. 1-14. Мінск: Беларуская навука (Навука і тэхніка)].

ÈSSÂ - Trubačev, Oleg. (1974 and the next). Ėtimologičeskij slovar' slavânskih âzykov. Praslavânskij leksičeskij fond. Issue 1-14. Moskva: Nauka. [Трубачев, Олег. (1974 и след.). Этимологический словарь славянских языков. Праславянский лексический фонд. Вып. 1-14. Москва: Наука].

ESUM - Mel'ničuk, Oleksandr (ed.). (1982-2012). Etimologičnij slovnik ukraïns'koï movi. Vol. 1-6. Kiïv: Naukova dumka. [Мельничук, Олександр (рэд.). (1982-2012). Етимологічний словник української мови. Т. 1-6. Київ: Наукова думка]. 
Fasmer, Maks. (1964-1973). Ètimologičeskij slovar' russkogo âzyka. Transl. from German and Append. Olega Trubačeva. Vol. 1-4. Moskva: Progress. [Фасмер, Макс. (1964-1973). Этимологический словарь русского языка. Перев. с нем. и дополн. Олега Трубачева. Т. 1-4. Москва: Прогресс].

Federowski, Michał. (1897-1981). Lud białoruski na Rusi Litewskiej. Materiaty do etnografii słowiańskiej zgromadzone $w$ latach 1877-1905. Vol. 1-8. Vol. 4 (1935): Przysłowia, żarciki, wyrażenia stałe oraz zagadki ludu, mieszczan i zagrodowców z okolic Grodna, Sokółki, Białegostoku, Bielska, Wołkowyska, Słonima, Nowogródka, Stucka, Lidy, Wilejki, Święcian i Oszmiany. Warszawa: Towarzystwo Naukowe Warszawskie.

GSBM - Bulyka, Alâksandr (ed.). (1982-2017). Gistaryčny sloǔnik belaruskaj movy. Issue 1-37. Mìnsk: Navuka ì tèhnìka (Belaruskaâ navuka). [Булыка, Аляксандр (рэд.). (19822017). Гістарычны слоўнік беларускай мовы. Вып. 1-37. Мінск: Навука і тэхніка (Беларуская навука)].

Kaspârovič, Mìkola. (1927). Vicebskì kraëvy sloǔnik: matar'âly. Vìcebsk: Vydan'ne Vìcebskaga Akrugovaga Tavarystva Kraâznaǔstva ì vydavectva 'Zarâ Zapada'. [Каспяровіч, Мікола. (1927). Віцебскі краёвы слоунік: матар'яль. Віцебск: Выданьне Віцебскага Акруговага Таварыства Краязнаўства і выдавецтва 'Заря Запада'].

Kryval'cèvìc, Raâ. (2016). Blizkì svet: hatni sloǔnik-uspamìn. Mìnsk: Tèhnalogîa. [Крывальцэвіч, Рая. (2016). Блізкі свет: хатні слойнік-успамін. Мінск: Тэхналогія].

LABNG - Bìryla, Mikalaj; Mackevič, Ûzèfa (eds.). (1993-1998). Leksičny atlas belaruskih narodnyh gavorak. T. 2. 1994: Sel'skâ̂ gaspadarka. Mìnsk: Nacyânal'naâ akadèmiâ navuk Belarusì. Instytut movaznaǔstva ìm. Âkuba Kolasa. [Бірыла, Мікалай; Мацкевіч, Юзэфа (рэд.). (1993-1998). Лексічны атлас беларускіх народных гаворак. Т. 2. 1994: Сельская гаспадарка. Мінск: Нацыянальная акадэмія навук Беларусі. Інстытут мовазнаўства ім. Якуба Коласа].

Lastoǔskì, Vaclaǔ. (1924). Padručny rasìjska-kryǔskì (belaruski) sloǔnik. Koŭna: Drukarnâ A. Baka. [Ластоўскі, Вацлаў. (1924). Падручны расійска-крыўскі (беларускі) слоўнік. Коўна: Друкарня А. Бака].

Machek, Václav. (1968). Etymologický slovník jazyka českého. The $2^{\text {nd }}$ edition corrected and added. Praha: Academia, Nakladatelství Československé akademie věd.

Materiały do słownika białorusko-polskiego, zebrane przez Michała Federowskiego. Vol. 1. Słownik języka białoruskiego. Materiały językowe, właściwości mowy. In: Archiwum Michała Federowskiego. Zbiory specjalne Biblioteki Uniwersytetu Warszawskiego. Oddziat rękopisów. No. 444.

Nasovič, İvan. (1983). Sloǔnik belaruskaj movy. Mìnsk: Belaruskaâ Saveckaâ Èncyklapedyâ. [Насовіч, Іван. (1983). Слоўнік беларускай мовы. Мінск: Беларуская Савецкая Энцыклапедыя].

Orel, Vladimir. (2007). Russian Etymological Dictionary. Vol. 2: K-O. Calgary: Octavia. Pacûpa, Ûry. (2007). Kryvìckì leksykon: sloǔnìk-dètèktyǔ. Arche, 3, pp. 159-211. [Пацюпа, Юры. (2007). Крывіцкі лексыкон: слоўнік-дэтэктыў. Arche, 3, с. 159-211]. 
PGS - Bulyka, Alâksandr (ed.). (2013). Padručny gìstaryčny sloǔnik substantyǔnaj leksikì. Vol. 1-2. Mìnsk: Belaruskaâ navuka. [Булыка, Аляксандр Мікалаевіч (рэд.). (2013). Падручны гістарычны слоўнік субстантыўнай лексікі. Т. 1-2. Мінск: Беларуская навука].

Ragaǔcoǔ, Vasil'. (2002. 16 october). Matčynyâ slovy: Z leksikì strèšynskaj gavorkì. Naša slova. [Рагаўцоў, Васіль Іванавіч. (2002. 16 кастр.). Матчыныя словы: 3 лексікі стрэшынскай гаворкі. Нама слова].

Šatalava, Lûboǔ. (1975). Belaruskae dyâlektnae slova. Mìnsk: Navuka ì tèhnika. [Шаталава, Любоў. (1975). Беларускае дыяллектнае слова. Мінск: Навука і тэхніка].

Schuster-Šewc, Heinz. (1978-1996). Historisch-etymologisches Wörterbuch der oder- und niedersorbichen Sprache. Bd. 1-5. Bautzen: VEB Domowina-Verlag.

Seržputoǔskì, Alâksandr. Prykazkì ì prymaǔkì belarusaǔ (manuscript; Mìnsk: İnstytut mastactvaznaǔstva, ètnagrafì̀ ì fal'kloru ìmâ K. Krapìvy NAN Belarusì). [Сержпутоўскі, Аляксандр. Прыказкі і прымаўкі беларусай (рукапіс; Мінск: Інстытут мастацтвазнаўства, этнаграфіі і фальклору імя К. Крапівы НАН Беларусі)].

SIPZB - Mackevič, Ûzèfa (ed.). (1979). Sloǔnik belaruskih gavorak paǔnočna-zahodnâj Belarusì ì âe pagraničča. Vol. 1. Mìnsk: Navuka ì tèhnìka. [Мацкевіч, Юзэфа (ed.). (1979). Слоўнік беларускіх гаворак паўночна-заходняй Беларусі і яе пагранічча. Т. 1. Мінск: Навука і тэхніка].

Smułkowa, Elżbieta (ed.). (2009). Brasławszczyzna. Pamięć i wspótczesność. Vol. 2. Stownictwo dwujęzycznych mieszkańców rejonu (Stownik brasławski). Warszawa: Wydawnictwa Uniwersytetu Warszawskiego.

SP - Sławski, Franciszek (ed.). (1974 and the next). Stownik prasłowiański. WrocławWarszawa-Kraków-Gdańsk: Zakład Narodowy im. Ossolińskich, Wydawnictwo PAN.

Stankevič, Ân. (1990). Belorussko-russkij (Velikolitovsko-russkij) slovar' / Belaruska-rasijski (Vâlikalitoy̆ska-rasijski) sloy̆nik / Byelorussian-russian (Greatlitvan-Russian) Dictionary. New York: Lew Sapieha Greatlitvan (Byelorussian) Foundation. [Станкевіч, Ян. (1990). Белорусско-русский (Великолитовско-русский) словарь / Беларуска-расійскі (Вялікалітоуска-расійскі) слоўнік / Byelorussian-russian (Greatlitvan-Russian) Dictionary. New York: Lew Sapieha Greatlitvan (Byelorussian) Foundation].

Timčenko, Êvgen (ed.). (2002-2003). Materiali do slovnika pisemnoï ta knižnoï ukraïns'koï movi XV-XVIII st. Book 1-2. Kiïv-N'û-Jork: İnstitut ukraïns'koï movi NAN Ukraïni [Тимченко, Євген (рэд.). (2002-2003). Матеріали до словника писемної та книжної української мови XV-XVIII cm. Кн. 1-2. Київ-Нью-Йорк: Інститут української мови НАН України].

TS - Kryvìckì, Alâksandr (ed.). (1982-1987). Turaǔskì sloǔnik. Vol. 1-5. Mìnsk: Navuka ì tèhnika. [Крывіцкі, Аляксандр (рэд.). (1982-1987). Тураўскі слоўнік. Т. 1-5. Мінск: Навука і тэхніка].

TSBM - Atrahovìč, Kandrat (Krapiva Kandrat) (ed.). (1977-1984). Tlumačal'ny sloǔnik belaruskaj movy. Vol. 1-5. Mìnsk: Belaruskaâ Saveckaâ Ėncyklapedyâ. [Атраховіч, Кандрат Кандратавіч (Крапіва Кандрат) (рэд.). (1977-1984). Тлумачальны слоўнік беларускай мовы. Т. 1-5. Мінск: Беларуская Савецкая Энцыклапедыя]. 
Ûrčanka, Georgìj. (1969). Narodnaâ sìnanimika. Mìnsk: Navuka ì tèhnikka. [Юрчанка, Георгій. (1969). Народная сінаніміка. Мінск: Навука і тэхніка].

Volkaŭ, İvan. (2016). Polackiâ dyâmenty: dyâlektny sloŭnik. Mìnsk: Belaruskaâ navuka. [Волкаў, Іван. (2016). Полачкія дыяяменты: дыялектны слоўнік. Мінск: Беларуская навука].

Vušacki slovazbor Rygora Baradulina. (2014). Mensk: Knìgazbor. [Вушаикі словазбор Рыгора Барадуліна. (2014). Менск: Кнігазбор].

ŽNS - Kuncèvič, Lûboǔ; Âškin, İvan (eds.). (2001). Žyvoe naša slova: dyâlektalagičny zbornik. Mìnsk: Belaruskaâ navuka. [Кунцэвіч, Любоў; Яшкін, Іван (рэд.). (2001). Жывое нама слова: дыялекталагічны зборнік. Мінск: Беларуская навука].

\section{References}

Âkobson, Gunar. (1969). Celi i metody ètimologizacii slov, vyražaûsih nekotorye abstraktnye ponâtiâ. In: Žanna Varbot and others (eds.). Ėtimologiâ 1967 (pp. 32-35). Moskva: Nauka. [Якобсон, Гунар. (1969). Цели и методы этимологизации слов, выражающих некоторые абстрактные понятия. В: Жанна Варбот и др. (ред.). Этимология 1967 (с. 32-35). Москва: Наука].

Gorâčeva, Tat'âna. (2007). Vostočnoslavânskie ètimologii. In: Žanna Varbot (ed.). Ètimologiâ 2003-2005 (pp. 37-48). Moskva: Nauka. [Горячева, Татьяна. (2007). Восточнославянские этимологии. В: Жанна Варбот (ред.). Этимология 2003-2005 (с. 37-48). Москва: Наука].

Gorbač, Oleksa. (1966). Arg̀o ukraïns'kih školârìv ì studentìv. In: Naukovì zapiski Ukrä̈s'kogo Vil'nogo Universitetu. 1964-1966. Filosofičnij Fakul'tet. Mûnhen: [s.n.]. Part. 8, pp. 3-55. [Горбач, Олекса. (1966). Арго українських школярів і студентів. У: Наукові записки Українського Вільного Університету. 1964-1966. Філософічний Факультет. Мюнхен: [s.n.]. Ч. 8, c. 3-55].

Lastoǔskì, Vaclaŭ. (1997). Vybranyâ tvory. Mìnsk: Belaruskì knìgazbor. [Ластоўскі, Вацлаў. (1997). Выбраныя творы. Мінск: Беларускі кнігазбор].

Otrębski, Jan. (1965). Gramatyka języka litewskiego. T. 2. Nauka o budowie wyrazów. Warszawa: Państwowe Wydawnictwo Naukowe.

Scâcko, Pavel. (1977). Belaruskae narodnae slovaǔtvarènne. Afiksal'nyâ nazoǔnikì. Mìnsk: Navuka ì tèhnìka. [Сцяцко, Павел. (1977). Беларускае народнае словаўтварэнне. Афіксальныя назойнікі. Мінск: Навука і тэхніка].

Sławski, Franciszek. (2011). Stowotwórstwo, stownictwo i etymologia stowiańska. Kraków: Polska Akademia Umiejętności.

Stašajtene, Valentina. (1973). Abstraktnaâ leksika: na materiale starobelorusskih pis'mennyh pamâtnikov XV-XVII vekov. Vil'nûs: Periodika. [Сташайтене, Валентина. (1973). Абстрактная лексика: на материале старобелорусских письменных памятников $X V-X V I I$ веков. Вильнюс: Периодика].

Vèksler, Pol. (2004). Gistaryčnaâ fanalogiâ belaruskae movy. Transl. from English A. Litvìnoǔskaâ, M. Ramanoǔskì. Mìnsk: Vydavec İ. P. Logvìnaǔ. [Вэкслер, Пол. 
Pobrane z czasopisma Studia Bia?orutenistyczne http://bialorutenistyka.umcs.pl Data: 26/04/2023 12:36:24

The Etymological Commentary on Word Formation of Abstract Nouns...

(2004). Гістарычная фаналогія беларускае мовы. Перакл. 3 англ. А. Літвіноўская, М. Раманоўскі. Мінск: Выдавец І. П. Логвінаў].

Žuravlev, Anatolij. (2005). Azzyk i mif: lingvističeskij kommentarij k trudu A. N. Afanas'eva «Poètičeskie vozzreniâ slavân na prirodu». Moskva: Izdatel'stvo 'Indrik'. [Журавлев, Анатолий. (2005). Язык и миф: лингвистический комментарий к труду А. Н. Афанасьева «Поэтические воззрения славян на природу». Москва: Издательство „Индрик”].

Article submission date: 21 January 2019 